\title{
Halomonas andesensis sp. nov., a moderate halophile isolated from the saline lake Laguna Colorada in Bolivia
}

Correspondence

Jorge Quillaguamán

Jorge.Quillaguaman@biotek.lu.se

\author{
Daniel Guzmán, ${ }^{1,2}$ Jorge Quillaguamán, ${ }^{1,2}$ Marlene Muñoz ${ }^{1}$ \\ and Rajni Hatti-Kaul ${ }^{1}$
}

\author{
${ }^{1}$ Department of Biotechnology, Center for Chemistry and Chemical Engineering, Lund University, \\ PO Box 124, SE-221 00 Lund, Sweden \\ ${ }^{2}$ Centro de Biotecnología, Facultad de Ciencias y Tecnología, Universidad Mayor de San Simón, \\ Cochabamba, Bolivia
}

\begin{abstract}
A moderately halophilic, motile, Gram-negative, rod-shaped bacterium, strain LC6 ${ }^{\top}$, was isolated from a water sample of lake Laguna Colorada in the Bolivian Andes. The major cellular fatty acids were $\mathrm{C}_{18: 1} \omega 7 c$, iso- $\mathrm{C}_{16: 1} \omega 7 c 2-\mathrm{OH}, \mathrm{C}_{16: 0}$ and $\mathrm{C}_{12: 0} 3-\mathrm{OH}$. The respiratory ubiquinones found in strain LC6 ${ }^{\top}$ were Q-9 (97\%) and Q-8 (3\%). Strain LC6 ${ }^{\top}$ was aerobic, heterotrophic, and able to utilize various carbohydrates and other substrates as carbon source. The $\mathrm{G}+\mathrm{C}$ content of the genomic DNA of strain $\mathrm{LC}^{\top}$ was 52.5 mol\%. The organism was able to grow at $\mathrm{pH} 6.0-11.0$ (optimum, pH 7.0-8.0), at $4-45{ }^{\circ} \mathrm{C}$ (optimum, 30-35 ${ }^{\circ} \mathrm{C}$ ) and in the presence of $0.5-20 \%(\mathrm{w} / \mathrm{v}$ ) $\mathrm{NaCl}$ (optimum, 1-3\%, w/v). Based on 16S rRNA gene sequence analysis, strain $\mathrm{LC}^{\top}{ }^{\top}$ was most closely related to Halomonas hydrothermalis DSM $15725^{\top}$ and Halomonas venusta DSM $4743^{\top}$ (98.8\% similarity), followed by Halomonas aquamarina DSM $30161^{\top}$, Halomonas axialensis DSM $15723^{\top}$ and Halomonas meridiana DSM $5425^{\top}(98.4 \%)$. However, levels of DNA-DNA relatedness between strain $\mathrm{LC}^{\top}$ and the above type strains were low $(<31 \%)$. Strain $\mathrm{LC}^{\top}$ resembled recognized Halomonas species with respect to various physiological, biochemical and nutritional characteristics. Combined phenotypic data and DNA-DNA hybridization data supported the conclusion that strain $L C 6^{\top}$ represents a novel species of the genus Halomonas, for which the name Halomonas andesensis is proposed. The type strain is LC6 $^{\top}$ (=CCUG $54844^{\top}=$ LMG $24243^{\top}=$ DSM $19434^{\top}$ ).
\end{abstract}

Micro-organisms requiring salt for growth, the halophiles, are found among all the domains of life, the Archaea, Eucarya and Bacteria (Oren, 2002). The different branches of the phylum Proteobacteria have various halophilic representatives with close relatives that are non-halophilic (Oren, 2002). Among the bacterial families that form part of the class Gammaproteobacteria, the family Halomonadaceae is mainly represented by halophilic and halotolerant species belonging to different genera. Halomonas is the largest genus in this family with, at the time of writing, more than 50 recognized species. Identification of Halomonas species requires data from polyphasic studies owing to the phenotypic heterogeneity of the genus.

The GenBank/EMBL/DDBJ accession number for the $16 \mathrm{~S}$ rRNA gene sequence of strain LC6 ${ }^{\top}$ is EF622233.

Maximum-parsimony and minimum-evolution phylogenetic trees based on 16S rRNA gene sequences showing the position of strain LC6 ${ }^{\top}$ among some members of the genus Halomonas are available as supplementary material with the online version of this paper.
This paper describes the phylogenetic and phenotypic characterization of a moderate halophile, strain LC6 $^{\mathrm{T}}$, isolated from a liquid sample collected from the saline lake Laguna Colorada located in the south-western part of Bolivia $\left(22^{\circ} 12^{\prime} \mathrm{S} 67^{\circ} 49^{\prime} \mathrm{W}\right)$ at $4300 \mathrm{~m}$ above sea level. Laguna Colorada owes its name to the bright red coloration provided by algae and halophilic micro-organisms.

Strain LC6 $^{\mathrm{T}}$ was isolated by using HM medium (Quillaguamán et al., 2004), based on a medium described by Ventosa et al. (1982), containing $5 \%$ (w/v) $\mathrm{NaCl}$. The isolation procedure consisted of suspending $1 \mathrm{ml}$ lake water into a 250-ml Erlenmeyer flask containing $100 \mathrm{ml}$ medium and incubating for 2 days at $30{ }^{\circ} \mathrm{C}$ with shaking at 200 r.p.m. The enriched bacterial medium was diluted $\left(10^{4}\right.$ fold) with sterile liquid medium, and then surfaceinoculated onto solid HM medium with $2 \%$ (w/v) agar and incubated for 3 days at $30{ }^{\circ} \mathrm{C}$.

HM medium was used for bacterial growth and characterization unless indicated otherwise. Reference strains Halomonas venusta DSM $4743^{\mathrm{T}}$, Halomonas meridiana DSM $5425^{\mathrm{T}}$, 
Halomonas aquamarina DSM $30161^{\mathrm{T}}$, Halomonas axialensis DSM $15723^{\mathrm{T}}$ and Halomonas hydrothermalis DSM $15725^{\mathrm{T}}$ were cultured under similar conditions as those used for characterization of strain $\mathrm{LC}^{\mathrm{T}}$.

Growth and tolerance to salt concentration, temperature and $\mathrm{pH}$ were studied by culturing strain $\mathrm{LC}^{\mathrm{T}}$ in $12 \mathrm{ml}$ HM medium in 50-ml screw-capped bottles (with shaking at 200 r.p.m.). For these studies, cells were grown in the presence of $0,0.5,1,2,3,5,8,15,20,25$ and $30 \%(\mathrm{w} / \mathrm{v})$ $\mathrm{NaCl}$ for 10 days at $\mathrm{pH} 7.5$ and $30{ }^{\circ} \mathrm{C}$; at $0,4,25,30,35,45$ and $50{ }^{\circ} \mathrm{C}$ for 14 days at $\mathrm{pH} 7.5$ and with $3 \%(\mathrm{w} / \mathrm{v}) \mathrm{NaCl}$; and at $\mathrm{pH} 4,5,6,7,8,9,10$ and 11 (adjusted with $5 \mathrm{M}$ $\mathrm{NaOH}$ or $2 \mathrm{M} \mathrm{HCl}$ ) for 10 days at $30{ }^{\circ} \mathrm{C}$ and with $3 \%$ $(\mathrm{w} / \mathrm{v}) \mathrm{NaCl}$. Growth rates were determined by monitoring the optical density (OD) of the culture broth at $600 \mathrm{~nm}$ during cultivation compared with sterile HM medium as the reference by using an Ultrospec 3000 spectrophotometer (Pharmacia Biotech). OD values were plotted to determine optimal conditions for growth.

Cell size and morphology were examined from bacterial cultures grown for $20 \mathrm{~h}$ by using a Nikon Optiphot-2 phase-contrast microscope at $1000 \times$ magnification. Gram staining was performed by using a Difco Gram stain set.

Acid production by strain LC6 $^{\mathrm{T}}$ from different carbon sources was analysed as described by Smibert \& Krieg (1994) in medium containing $1 \%(\mathrm{w} / \mathrm{v})$ carbon source, $0.3 \%(\mathrm{w} / \mathrm{v})$ yeast extract and $9 \%(\mathrm{w} / \mathrm{v})$ sea salts (Sigma) (Sánchez-Porro et al., 2003).

Growth of strain LC6 $^{\mathrm{T}}$ and the five reference Halomonas strains on different carbon sources was analysed in medium containing $(\mathrm{w} / \mathrm{v}): 0.01 \%$ yeast extract, $3.0 \%$ $\mathrm{NaCl}, \quad 0.025 \% \quad \mathrm{MgSO}_{4} .7 \mathrm{H}_{2} \mathrm{O}, \quad 0.009 \% \quad \mathrm{CaCl}_{2} \cdot 2 \mathrm{H}_{2} \mathrm{O}$, $0.05 \% \mathrm{KCl}, 0.006 \% \mathrm{NaBr}$ and $0.5 \%$ carbon source. As a reference, each strain was grown in the same medium without carbon source.

Hydrolysis of gelatin, casein, starch, Tween 80 and DNA was determined as described by Sánchez-Porro et al. (2003). Other biochemical characteristics were screened by using conventional methods according to Smibert \& Krieg (1994). In all cases, $9 \%(\mathrm{w} / \mathrm{v})$ sea salts (Sigma) was added to the medium.

Susceptibility to antibiotics was determined by using the standard disc assay method (Smibert \& Krieg, 1994). Resistance and degree of susceptibility were determined by measuring the size of inhibition zones after $30 \mathrm{~h}$ incubation in $\mathrm{HM}$ medium containing $3 \%(\mathrm{w} / \mathrm{v}) \mathrm{NaCl}$ at $30{ }^{\circ} \mathrm{C}$ in the presence of different concentrations of the various antibiotics.

Colony morphology was analysed according to Smibert \& Krieg (1994) after growth for $30 \mathrm{~h}$ at $30^{\circ} \mathrm{C}$ on solid HM medium. Bacterial flagella were observed by using a JEM123 (HC) transmission electron microscope after staining with $2 \%(\mathrm{v} / \mathrm{v})$ uranyl acetate, according to Vreeland et al. (1980).
Genomic DNA was extracted and purified according to Arahal et al. (2002), and its purity was assessed from $A_{260} /$ $A_{280}$ and $A_{260} / A_{230}$ ratios (Johnson, 1994). The $16 \mathrm{~S}$ rRNA gene of strain $\mathrm{LC}^{\mathrm{T}}$ was amplified, purified and sequenced as described by Quillaguamán et al. (2004). The GenBank and RDP databases were used to search for similar $16 \mathrm{~S}$ rRNA gene sequences (Maidak et al., 2000). Phylogenetic analysis based on 16S rRNA gene sequences was performed via the MEGA2 software package (Kumar et al., 2001). For tree construction, only sequences from the type strains of recognized species were taken into account. The 16S rRNA gene sequence of strain LC6 $^{\mathrm{T}}$ comprised $1408 \mathrm{bp}$.

Determination of DNA G+C content and DNA-DNA hybridization experiments were performed by the Deutsche Sammlung von Mikroorganismen und Zellkulturen (DSMZ, Braunschweig, Germany). For determination of the DNA G+C content, DNA of strain $\mathrm{LC}^{\mathrm{T}}$ was hydrolysed with P1 nuclease and nucleotides were dephosphorylated with bovine alkaline phosphatase (Mesbah et al., 1989). The resulting deoxyribonucleosides were analysed by HPLC (Shimadzu) with chromatography conditions adapted from Tamaoka \& Komagata (1984). The DNA G + C content was calculated from the ratio of deoxyguanosine $(\mathrm{dG})$ and deoxythymidine $(\mathrm{dT})$ according to the method of Mesbah et al. (1989). For these experiments, strain LC6 $^{\mathrm{T}}$ was grown in HM medium containing $3 \%(\mathrm{w} / \mathrm{v}) \mathrm{NaCl}$. DNA-DNA hybridization experiments between strain $\mathrm{LC}^{\mathrm{T}}$ and the five Halomonas reference strains were performed. The organisms were grown in HM medium. DNA was isolated by chromatography on hydroxyapatite according to the procedure of Cashion et al. (1997). DNA-DNA hybridization was carried out as described by De Ley et al. (1970) with the modifications described by Huß et al. (1983) and Escara \& Hutton (1980) by using a model 2600 spectrophotometer equipped with a model $2527-\mathrm{R}$ thermoprogrammer and plotter (Gilford Instrument Laboratories). Renaturation rates were computed with the TRANSFER BAS program of Jahnke (1992).

The cellular fatty acids of strain LC $^{\mathrm{T}}$ were analysed by GC at the Belgian Coordinated Collections of Micoorganisms (BCCM) after growth at $28{ }^{\circ} \mathrm{C}$ on tripticase soy agar for $24 \mathrm{~h}$. Inoculation and harvesting of cells were performed according to the recommendations of the commercial identification MIDI system (Microbial Identification System, Inc.), except that cells were harvested from the whole plate (QALL) and from three plates (3PL) to obtain a sufficient concentration of fatty acids in the extract. Extraction and analysis were performed according to recommendations provided with the MIDI system. Respiratory quinone analysis was carried out using HPLC by the Indentification Service and Dr B. J. Tindall, DSMZ, Braunschweig, Germany.

Phylogenetic analysis with the neighbour-joining method based on 16S rRNA gene sequences placed strain LC6 $^{\mathrm{T}}$ 
within the genus Halomonas (Fig. 1). Strain $\mathrm{LC}^{\mathrm{T}}$ was related most closely to $H$. hydrothermalis DSM $15725^{\mathrm{T}}$ and H. venusta DSM $4743^{\mathrm{T}}$ (98.8\% $16 \mathrm{~S}$ rRNA gene sequence similarity), followed by $H$. aquamarina DSM $30161^{\mathrm{T}}, H$. axialensis DSM $15723^{\mathrm{T}}$ and $H$. meridiana DSM $5425^{\mathrm{T}}$ (98.4\%). Phylogenetic trees based on the maximumparsimony and minimum-evolution methods showed a similar relationship between strain LC $^{\mathrm{T}}$ and the Halomonas species examined in Fig. 1 (see Supplementary Fig. S1a and b in IJSEM Online).

Cells of strain $\mathrm{LC}^{\mathrm{T}}$ were motile by means of lophotrichous flagella. Cells were Gram-negative rods that divided in duplets during the exponential phase of growth. Colonies of strain LC6 $^{\mathrm{T}}$ were circular.

Strain LC6 $^{\mathrm{T}}$ was able to grow in the presence of $0.5-20 \%$ $(\mathrm{w} / \mathrm{v}) \mathrm{NaCl}$ (optimal growth at $1-3 \%$, w/v). It grew at temperatures from $4{ }^{\circ} \mathrm{C}$ (the lowest temperature tested was $0{ }^{\circ} \mathrm{C}$ ) to $45{ }^{\circ} \mathrm{C}$ (optimal growth at $30-35{ }^{\circ} \mathrm{C}$ ). A minimum growth temperature of $4{ }^{\circ} \mathrm{C}$ has been reported for $H$. meridiana, $H$. venusta and $H$. hydrothermalis (Table 1 ). Strain LC6 $^{\mathrm{T}}$ was able to grow over a broad $\mathrm{pH}$ range (Table 1).

Table 1 provides a comparison of various features of strain LC $^{\mathrm{T}}{ }^{\mathrm{T}}$ with phylogenetically most closely related Halomonas species. Strain LC6 $^{\mathrm{T}}$ was aerobic and heterotrophic and was able to assimilate a diverse range of carbon sources (as with the other Halomonas species investigated); however, strain LC6 $^{\mathrm{T}}$ showed various differences from the Halomonas reference strains with respect to certain nutritional and biochemical characteristics (Table 1).

Strain LC6 $^{\mathrm{T}}$ was unable to grow in minimal medium containing a single defined carbon source. It was therefore not possible to characterize this novel strain by using kits such as Biolog, as previously performed for other reference strains (Kaye et al., 2004; Mata et al., 2002). Strain LC6 ${ }^{\mathrm{T}}$ and the five reference strains were thus grown in medium

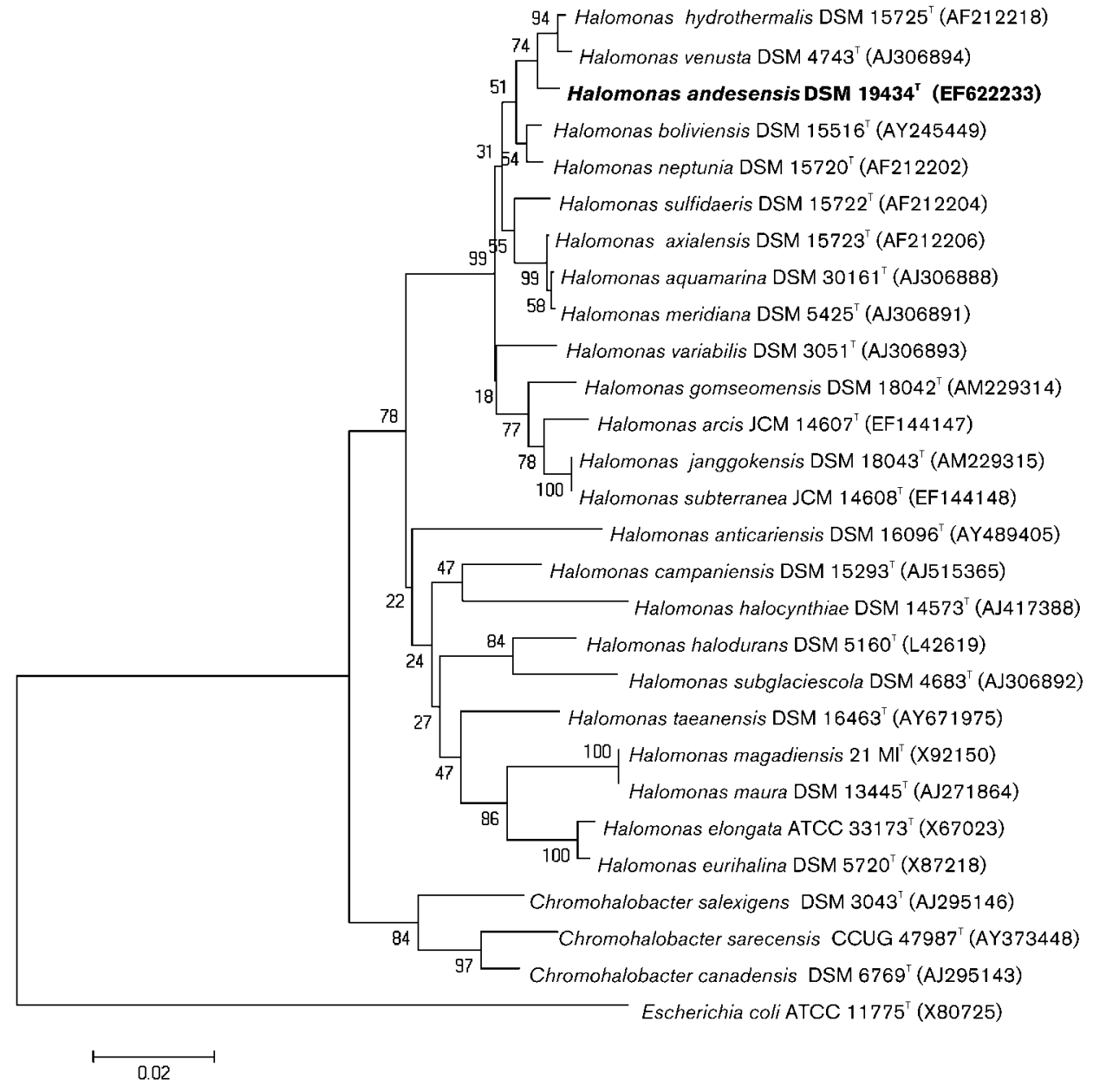

Fig. 1. Neighbour-joining phylogenetic tree based on $16 \mathrm{~S}$ rRNA gene sequences showing the position of strain LC6 ${ }^{\top}$ (=DSM $19434^{\top}$ ) among some members of the genus Halomonas. Escherichia coli ATCC $11775^{\top}$ was used as an outgroup. Numbers at branch points are bootstrap values (percentages of 500 resamplings). Bar, 2 substitutions per $100 \mathrm{nt}$. 
Table 1. Differential characteristics between strain $\mathrm{LC}^{\top}$ and the type strains of related Halomonas species

Strains: 1 , LC6 ${ }^{\mathrm{T}}$ (H. andesensis sp. nov.); 2, H. venusta DSM $4743^{\mathrm{T}} ; 3$, H. meridiana DSM 5425 $5^{\mathrm{T}} ; 4$, H. aquamarina DSM $30161^{\mathrm{T}}$; 5 , H. axialensis DSM $15723^{\mathrm{T}} ; 6$, H. hydrothermalis DSM $15725^{\mathrm{T}}$. +, Positive; - , negative; $\mathrm{w}+$, weakly positive. All stains are Gram-negative, motile rods. All are negative for hydrolysis of aesculin and gelatin. Colonies of all strains have entire margins.

\begin{tabular}{|c|c|c|c|c|c|c|}
\hline Characteristic & 1 & 2 & 3 & 4 & 5 & 6 \\
\hline Temperature range $\left({ }^{\circ} \mathrm{C}\right)$ & $4-45$ & $4-45$ & $4-45$ & $4-35$ & $0-35$ & $4-35$ \\
\hline Total salts (\%, optimum) & $1-3$ & $0.5-5$ & $1-3$ & 8 & 5 & $5-8$ \\
\hline $\mathrm{pH}$ range & $6-11$ & $5-11$ & $5-11$ & $5-10$ & $5-11$ & $5-11$ \\
\hline $\mathrm{NO}_{3}^{-}$reduction & + & + & - & + & + & + \\
\hline Pigmentation & Cream & Cream & White & Cream & Cream & Cream \\
\hline \multicolumn{7}{|l|}{ Hydrolysis of: } \\
\hline Starch & + & - & + & + & - & - \\
\hline Tween 80 & - & - & + & + & - & - \\
\hline \multicolumn{7}{|l|}{ Acid production from: } \\
\hline Lactose & + & + & + & + & - & + \\
\hline L-Arabinose & + & + & - & + & + & + \\
\hline D-Mannitol & - & + & + & + & + & - \\
\hline L-Rhamnose & - & + & + & + & + & + \\
\hline Trehalose & + & + & + & + & + & - \\
\hline \multicolumn{7}{|l|}{ Growth on: } \\
\hline L-Arabinose & + & - & - & - & - & + \\
\hline Cellobiose & + & - & - & - & - & - \\
\hline Citric acid & - & + & - & - & - & - \\
\hline D-Fructose & $\mathrm{w}+$ & + & - & + & - & + \\
\hline D-Galactose & + & + & - & - & - & + \\
\hline D-Gluconic acid & + & + & - & + & + & - \\
\hline Itaconic acid & - & + & - & - & - & + \\
\hline L-Lactic acid & + & + & - & - & - & + \\
\hline Lactose & - & - & $\mathrm{w}+$ & - & - & - \\
\hline Maltose & + & + & - & + & + & + \\
\hline myo-Inositol & + & + & - & $\mathrm{w}+$ & - & - \\
\hline Propionic acid & + & + & + & + & - & - \\
\hline Raffinose & + & + & $\mathrm{w}+$ & - & - & - \\
\hline L-Rhamnose & $\mathrm{w}+$ & $\mathrm{w}+$ & - & - & - & - \\
\hline Starch & + & + & + & + & + & - \\
\hline D-Xylose & + & - & - & $\mathrm{w}+$ & - & - \\
\hline Growth in minimal medium & - & + & + & + & + & + \\
\hline DNA G $+\mathrm{C}$ content $(\mathrm{mol} \%)^{*}$ & 52.5 & 52.3 & 59.5 & 58 & 57.6 & 56.3 \\
\hline
\end{tabular}

${ }^{\star}$ Data for reference strains were obtained from Kaye et al. (2004) and Mata et al. (2002).

containing yeast extract. Under these conditions, strain LC6 $^{\mathrm{T}}$ showed broader ability to utilize various carbon sources than the type strains of $H$. venusta and $H$. hydrothermalis (Table 1).

Growth of strain LC6 $^{\mathrm{T}}$ was inhibited by ampicillin, erythromycin, nalidixic acid, chloramphenicol and streptomycin (all at $10 \mu \mathrm{g}$ ).

The G $+\mathrm{C}$ content of the genomic DNA of strain $\mathrm{LC}^{\mathrm{T}}$ was $52.5 \mathrm{~mol} \%$, similar to that for $H$. venusta DSM $4743^{\mathrm{T}}$ but considerably lower than those for the other four reference Halomonas type strains (Table 1). Levels of DNA-DNA relatedness between strain $\mathrm{LC}^{\mathrm{T}}$ and $H$. hydrothermalis DSM $15725^{\mathrm{T}}$, H. venusta DSM $4743^{\mathrm{T}}$, H. aquamarina DSM
$30161^{\mathrm{T}}, H$. axialensis DSM $15723^{\mathrm{T}}$ and $H$. meridiana DSM $5425^{\mathrm{T}}$ were $30.2,32.3,23.3,27.3$ and $24.1 \%$, respectively. These values are lower than the recommended $70 \%$ for the delineation of novel species (Wayne et al., 1987).

Based on taxonomic differences and low levels of DNADNA relatedness with respect to its closest phylogenetic relatives, strain $\mathrm{LC}^{\mathrm{T}}$ is considered to represent a novel species of the genus Halomonas, for which we propose the name Halomonas andesensis sp. nov.

\section{Description of Halomonas andesensis sp. nov.}

Halomonas andesensis (an.de.sen'sis. N.L. fem. adj. andesensis pertaining to the Andes). 
Cells are aerobic, Gram-negative rods $(1.3 \times 1.8-$ $1.3 \times 3 \mu \mathrm{m})$ that occur primarily singly. Cells are motile with lophotrichous flagella. Colonies are circular with entire margins, convex, smooth and cream-coloured. Growth occurs at $4-45{ }^{\circ} \mathrm{C}$ (optimum, $30-35{ }^{\circ} \mathrm{C}$ ), at pH 6-11 (optimum, pH 7-8) and in the presence of 0.5$20 \%$ (w/v) $\mathrm{NaCl}$ (optimum, $1-3 \%$, w/v). Poly- $\beta$-hydroxyalkanoate is produced. Production of exopolysaccharide is negative. Oxidase- and catalase-positive. Negative for facultative anaerobic growth. Reduces nitrate to nitrite. Respiration on nitrate and nitrite is negative. Does not produce gas from nitrate. $\mathrm{H}_{2} \mathrm{~S}$ production from L-cysteine is negative. Starch is hydrolysed, but aesculin, casein, gelatin and Tween 80 are not. Negative for phenylalanine deaminase, Voges-Proskauer reaction, methyl red, indole production, lysine and ornithine decarboxylase. Urease activity is positive. Acid is produced from L-arabinose, D-fructose, D-galactose, lactose, myo-inositol, maltose, sucrose and trehalose, but not from D-mannitol or Lrhamnose. The following compounds are utilized as sole carbon sources: acetate, L-arabinose, cellobiose, D-fructose, galactose, D-gluconic acid, D-glucose, L-lactic acid, maltose, myo-inositol, propionic acid, raffinose, L-rhamnose, sucrose, starch and D-xylose. The following carbon sources are not utilized: citric acid, itaconic acid and lactose. Sensitive to ampicillin, erythromycin, nalidixic acid, chloramphenicol and streptomycin (at $10 \mu \mathrm{g}$ ). The DNA $\mathrm{G}+\mathrm{C}$ content of the type strain is $52.5 \mathrm{~mol} \%$. The major cell-wall fatty acids are $\mathrm{C}_{18: 1} \omega 7 c$, iso- $\mathrm{C}_{16: 1} \omega 7 c 2-\mathrm{OH}$, $\mathrm{C}_{16: 0}$ and $\mathrm{C}_{12: 0}$ 3-OH. Respiratory ubiquinones are Q-9 $(97 \%)$ and Q-8 (3\%).

The type strain, LC6 $^{\mathrm{T}} \quad\left(=\mathrm{CCUG} 54844^{\mathrm{T}}=\mathrm{LMG} \quad 24243^{\mathrm{T}}\right.$ $=$ DSM $19434^{\mathrm{T}}$ ), was isolated from a water sample of the lake Laguna Colorada in the Bolivian Andes.

\section{Acknowledgements}

We are grateful to the Swedish International Development Cooperation Agency (Sida) for supporting this work.

\section{References}

Arahal, D. R., Ludwig, W., Schleifer, K. H. \& Ventosa, A. (2002). Phylogeny of the family Halomonadaceae based on $23 \mathrm{~S}$ and $16 \mathrm{~S}$ rDNA sequence analyses. Int J Syst Evol Microbiol 52, 241-249.

Cashion, P., Holder-Franklin, M. A., McCully, J. \& Franklin, M. (1997). A rapid method for base ratio determination of bacterial DNA. Anal Biochem 81, 461-466.

De Ley, J., Cattoir, H. \& Reynaerts, A. (1970). The quantitative measurement of DNA hybridisation from renaturation rates. Eur $J$ Biochem 12, 133-142.

Escara, J. F. \& Hutton, J. R. (1980). Thermal stability and renaturation of DNA in dimethylsulphoxide solutions: acceleration of renaturation rate. Biopolymers 19, 1315-1327.
Huß, V. A. R., Festl, H. \& Schleifer, K. H. (1983). Studies on the spectrophotometric determination of DNA hybridization from renaturation rates. Syst Appl Microbiol 4, 184-192.

Jahnke, K. D. (1992). BASIC computer program for evaluation of spectroscopic DNA renaturation data from GILFORD SYSTEM 2600 spectrophotometer on a $\mathrm{PC} / \mathrm{XT} / \mathrm{AT}$ type personal computer. J Microbiol Methods 15, 61-73.

Johnson, J. L. (1994). Similarity analysis of DNAs. In Methods for General and Molecular Bacteriology, pp. 655-682. Edited by P. Gerhardt, R. G. E. Murray, W. A. Wood \& N. R. Krieg. Washington, DC: American Society for Microbiology.

Kaye, J. Z., Márquez, M. C., Ventosa, A. \& Baross, J. A. (2004). Halomonas neptunia sp. nov., Halomonas sulfidaeris sp. nov., Halomonas axialensis sp. nov. and Halomonas hydrothermalis sp. nov.: halophilic bacteria isolated from deep-sea hydrothermal-vent environments. Int J Syst Evol Microbiol 54, 499-511.

Kumar, S., Tamura, K., Jakobsen, I. B. \& Nei, M. (2001). MEGA2: molecular evolutionary genetic analysis software. Bioinformatics 17, 1244-1245.

Maidak, B. L., Coloe, J. R., Lilburn, T. G., Parker, C. T., Jr, Saxman, P. R., Stredwick, J. M., Garrity, G. M., Li, B., Olsen, G. J. \& other authors (2000). The RDP (Ribosomal Database Project) continues. Nucleic Acids Res 28, 173-174.

Mata, J. A., Martínez-Cánovas, J., Quesada, E. \& Victoria, B. (2002). A detailed phenotypic characterisation of the type strains of Halomonas species. Syst Appl Microbiol 25, 360-375.

Mesbah, M., Premachandran, U. \& Whitman, W. (1989). Precise measurement of the $\mathrm{G}+\mathrm{C}$ content of deoxyribonucleic acid by highperformance liquid chromatography. Int J Syst Bacteriol 39, 159-167.

Oren, A. (2002). Diversity of halophilic microorganisms: environments, phylogeny, physiology, and applications. J Ind Microbiol Biotechnol 28, 56-63.

Quillaguamán, J., Hatti-Kaul, R., Mattiasson, B., Alvarez, M. T. \& Delgado, O. (2004). Halomonas boliviensis sp. nov., an alkalitolerant, moderate halophile isolated from soil around a Bolivian hypersaline lake. Int J Syst Evol Microbiol 54, 721-725.

Sánchez-Porro, C., Martín, S., Mellado, E. \& Ventosa, A. (2003). Diversity of moderately halophilic bacteria producing extracellular hydrolytic enzymes. J Appl Microbiol 94, 295-300.

Smibert, R. M. \& Krieg, N. R. (1994). Phenotypic characterization. In Methods for General and Molecular Bacteriology, pp. 611-651. Edited by P. Gerhardt, R. G. E. Murray, W. A. Wood \& N. R. Krieg. Washington, DC: American Society for Microbiology.

Tamaoka, J. \& Komagata, K. (1984). Determination of DNA base composition by reversed-phase high-performance liquid chromatography. FEMS Microbiol Lett 25, 125-128.

Ventosa, A., Quesada, E., Rodríguez-Valera, F., Ruiz-Berraquero, F. \& Ramos-Cormenzana, A. (1982). Numerical taxonomy of moderately halophilic Gram-negative rods. J Gen Microbiol 128, 1959-1968.

Vreeland, R. H., Litchfield, C. D., Martin, E. L. \& Elliot, E. (1980). Halomonas elongata, a new genus and species of extremely salttolerant bacteria. Int J Syst Bacteriol 30, 485-495.

Wayne, L. G., Brenner, D. J., Colwell, R. R., Grimont, P. A. D., Kandler, O., Krichevsky, M. I., Moore, L. H., Moore, W. E. C., Murray, R. G. E. \& other authors (1987). International Committee on Systematic Bacteriology. Report of the ad hoc committee on reconciliation of approaches to bacterial systematics. Int J Syst Bacteriol 37, 463-464. 